Physical-biological interactions to the west of Hawaiian

Islands

\title{
Physical-biological interactions to the west of Hawaiian Islands: impact of submesoscale dynamics on biological productivity
}

\section{P. Xiu and F. Chai}

School of Marine Sciences, University of Maine, Orono, 04469 Maine, USA

Received: 26 June 2013 - Accepted: 19 July 2013 - Published: 26 July 2013

Correspondence to: P. Xiu (peng.xiu@maine.edu)

Published by Copernicus Publications on behalf of the European Geosciences Union.

Title Page

Abstract Introduction

Conclusions

References

Tables

Figures

14

$\rightarrow 1$

4

Back

Close

Printer-friendly Version 


\section{Abstract}

Abundant energetic eddies and frontal processes occur frequently to the west of Hawaiian Islands. Their impacts on biological productivity, however, are ambiguous because satellite-measured surface chlorophyll often shows a completely different pattern to 5 eddy kinetic energy field. Our study suggests a new mechanism of how those oceanic eddies and frontal processes affect phytoplankton dynamics by changing their physiological conditions. Due to eddy-eddy or eddy-front interactions, high eddy activity creates regions with enhanced shear and straining that leads to rapid upper ocean restratification and submesoscale vertical motions. The restratification process deceases mixed layer depth that increases the mean exposure of the phytoplankton cells to light, thus resulting in enhanced photosynthetic carbon-based production. In contrast, increased light in the surface layer could either decrease phytoplankton chlorophyll due to the photoacclimation effect or increase chlorophyll when light is a limiting factor for phytoplankton growth. Combined with another two competing processes for vertical nutrient flux, ocean restratification and submesoscale upward motions, it introduces different responses and uncertainties of observed chlorophyll-based production to eddy activity and frontal processes.

\section{Introduction}

The circulation pattern to the west of Hawaiian Islands located in the North Pacific subtropical gyre is known to be highly dynamic and energetic due to the complex interactions between wind, current, and the Hawaiian archipelago (e.g., Xie et al., 2001; Liu et al., 2003; Qiu and Chen, 2010; Sasaki et al., 2010; Yoshida et al., 2011). With surface drifters and hydrographic data, four major zonal currents have been identified in this region. Embedded in the large-scale, westward-flowing North Equatorial Current (NEC) spanning between $8^{\circ} \mathrm{N}$ and $30^{\circ} \mathrm{N}$, the eastward flowing North Pacific Subtropical Countercurrent (STCC) is mostly observed north of $24^{\circ} \mathrm{N}$. Driven by the far-reaching
BGD

10, 12529-12549, 2013

Physical-biological interactions to the west of Hawaiian

Islands

P. Xiu and F. Chai

Title Page

Abstract Introduction

Conclusions

Tables

References

Figures

14

4

Back

Full Screen / Esc

Printer-friendly Version

Interactive Discussion $\rightarrow 1$

Close

Interave Discussion 
effects of Hawaiian Islands blocking both northeasterly trade winds and NEC, a narrow eastward Hawaiian Lee Countercurrent (HLCC) is evident between $18^{\circ} \mathrm{N}$ and $21^{\circ} \mathrm{N}$. As the HLCC reaches the Hawaiian Islands, the current bifurcates into two branches. The northern branch flows along the island chain becoming the northwestward Hawaiian 5 Lee Current (HLC), and the southern branch merges into the westward flowing NEC. In this study, we focus on a spatial domain of $10-30^{\circ} \mathrm{N}$ in latitude and $160-210^{\circ} \mathrm{E}$ in longitude (Fig. 1), in which those zonal currents create a strong north-south velocity shear associated with abundant eddies induced by the combination of oceanic and atmospheric circulation system (Kobashi and Kawamura, 2002; Calil et al., 2008; Yoshida 10 et al., 2010; Jia et al., 2011).

The interaction between mesoscale eddies, as well as that between eddies and surrounding currents can create regions with enhanced shear and straining that sharpens existing horizontal density gradients and breaks the thermal wind balance. The imbalance in geostrophy by this frontogenesis process gives rise to submesoscale 15 ageostrophic overturning circulation with intense upward and downward water movements that converts density gradients from the horizontal to the vertical (Lapeyre et al., 2006; Mahadevan and Tandon, 2006). This slumping occurs where large straining affects existing horizontal density gradients and consequently results in rapid restratification in the upper ocean (Klein and Lapeyre, 2009). Other studies have also shown that mixed layer baroclinic instabilities can further accelerate the rate of slumping at a relatively shorter and smaller scales (Boccaletti et al., 2007; Fox-Kemper et al., 2008; Mahadevan et al., 2010).

The potential impact of this eddy-induced surface frontal adjustment to nutrients and phytoplankton dynamics are primarily through two mechanisms: restratification and upward motions. Ocean restratification that suppresses vertical mixing, can increase the mean exposure of the phytoplankton cells and thus trigger phytoplankton blooms that are mostly observed in high latitudes (Lévy et al., 1999; Taylor and Ferrari, 2011; Mahadevan et al., 2012). Upward motions facilitating vertical nutrient injections to the euphotic zone have also been proposed to stimulate elevated biological productivity
BGD

$10,12529-12549,2013$

Physical-biological interactions to the west of Hawailian

Islands

P. Xiu and F. Chai

Title Page

Abstract Introduction

Conclusions

Tables References Figures

14

4

Back

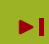

$>$

Close

Full Screen / Esc

Printer-friendly Version

Interactive Discussion 
patches (Lévy et al., 2001; Lehahn et al., 2007; Xiu et al., 2012). In the Lee of Hawaiian Islands, in addition to the wind-driven eddy pumping process, Calil and Richards (2010) observed transient chlorophyll "hot spots" from satellite and related them to the episodic nutrient injections at the submesoscale. To the further west (e.g., west of dateline), 5 however, satellite-derived high chlorophyll values are not commonly observed even with similar eddy activity as in the Lee of Hawaiian Islands (Calil et al., 2011). This usually leads to the conclusion that there are no statistical relationship between eddy activity and biological productivity in that region, especially on longer time scales. In this work, we will revisit this view and examine the potential impacts by eddies and 10 frontal processes on phytoplankton dynamics to the west of Hawaiian Islands using several different satellite observations.

\section{Data and methods}

Monthly and 8 day surface chlorophyll concentrations from the Sea-viewing Wide Field-of-view Sensor (SeaWiFS) with $9 \mathrm{~km}$ horizontal resolution during 1998-2007 15 were used in this study. For the same period and sampling frequency, two primary production estimates derived via SeaWiFS Vertically Generalized Production Model (VGPM; Behrenfeld and Falkowski, 1997) and SeaWiFS Carbon-based Production Model (CbPM; Westberry et al., 2008) were adopted to represent biological productivity. Mixed layer depth (MLD) was calculated from the Thermal Ocean Prediction Model

(TOPS) and the Simple Ocean Data Assimilation (SODA) data. A merged and gridded satellite product of MSLA (Maps of Sea Level Anomaly) and MADT (Maps of Absolute Dynamic Topography) distributed by the Archiving, Validation, and Interpretation of Satellite Oceanographic data (AVISO), which consist of maps at 7 day interval on a $0.25^{\circ}$ horizontal grid were used to calculate eddy kinetic energy (EKE) and absolute geostrophic velocities, respectively. Monthly surface wind products were obtained from QuickSCAT scatterometer. Measured annual-mean climatology of nitrate $\left(\mathrm{NO}_{3}\right)$ and silicate $\left(\mathrm{SiO}_{4}\right)$ obtained from World Ocean Atlas 2009 (WOA09; Garcia et al., 2010)
BGD

$10,12529-12549,2013$

Physical-biological interactions to the west of Hawaiian

Islands

P. Xiu and F. Chai

Title Page

Abstract Introduction

Conclusions

Tables References Figures

14

$\triangleleft$

Back

Full Screen / Esc

Printer-friendly Version

Interactive Discussion 
were used to calculate nutricline depth. Nutricline depth was estimated with a criterion of $1.0 \mathrm{mmolm}^{-3}$ increase from a reference depth of $10 \mathrm{~m}$.

To diagnose regions of large stretching and strain, we calculated the finite-size Lyapunov exponent (FSLE), which is the inverse time of the separation of adjacent particle 5 pairs. The FSLE is defined as

$\lambda=\frac{1}{\tau} \log \left(\frac{\delta_{f}}{\delta_{0}}\right)$

where $\delta_{0}$ and $\delta_{\mathrm{f}}$ are the initial and final distance of particle pairs, respectively, and $\tau$ is the time the particle pairs take to reach $\delta_{\mathrm{f}}$. In this study, we set $\delta_{0}$ and $\delta_{\mathrm{f}}$ to be $0.02^{\circ}$ and $0.5^{\circ}$, respectively to represent submesoscale processes. Absolute geostrophic velocities were used to calculate particle trajectories. Spatiotemporal interpolation of the velocity data was achieved by bilinear interpolation to grid points below the resolution of the altimetry data. Numerical integration was performed by using a standard fourthorder Runge-Kutta scheme.

The FSLE can be performed by calculating the separation of initially nearby particles as time moves forward or backward. In chaotic systems, forward and backward evolutions have been suggested to approximate stable and unstable manifolds of the flow field, respectively (d'Ovidio et al., 2004; Lehahn et al., 2007; Calil et al., 2011). Hyperbolic points are usually in the regions where unstable and stable manifolds cross each other. Tracers such as nutrients in these regions can be stretched along the unstable manifolds and compressed along the stable manifolds (d'Ovidio et al., 2009). Regions of large FSLEs from backward calculations are therefore prone to surface frontogenesis and are related to strong vertical velocities (Lehahn et al., 2007; Calil and Richards, 2010).

Islands

P. Xiu and F. Chai

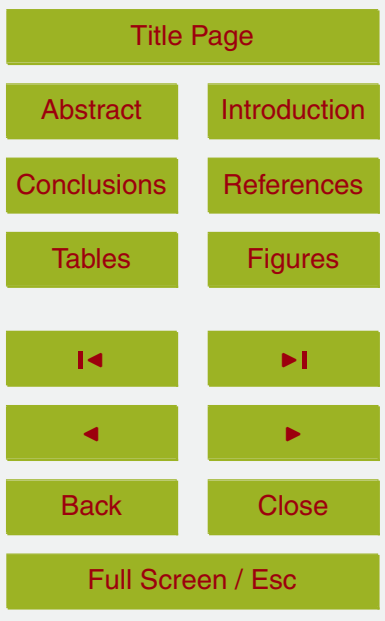

Printer-friendly Version 


\section{Results}

Two production products CbPM and VGPM were compared with in-situ measurements at a fixed station ALOHA (a long-term oligotrophic habitat assessment; $22^{\circ} 45^{\prime} \mathrm{N}$, $\left.158^{\circ} \mathrm{W}\right)$. VGPM derived primary production (PP) tends to underestimate the mean condition in that area (Fig. 1). CbPM derived PP that approximately doubles VGPM PP, lies in a reasonable range of observations. CbPM PP also indicates a closer timing of seasonal peaks to observations than VGPM PP. Both CbPM and VGPM PP, however, underestimate observed seasonal amplitudes.

To the west of Hawaiian Islands, a high EKE band spanning from $17^{\circ} \mathrm{N}$ to $27^{\circ} \mathrm{N}$ is evident in the mean condition (Fig. 2a). This EKE signal primarily results from enhanced eddy and frontal activities that might propagate from the east or be generated locally. In the immediate lee of the islands, one distinct region emerges with a EKE higher than $300 \mathrm{~cm}^{2} \mathrm{~s}^{-2}$. Its formation mechanism has been connected with the local wind stress curl associated with the blocking of the trade wind by the Hawaiian Islands. These eddies are usually confined to the lee of the island with a relatively short lifespan (e.g. a few weeks). Away from the immediate lee, both local wind stress curl and current instability are responsible for the observed high EKE band.

Mean FSLE during 1998-2007 indicates a similar spatial pattern as EKE, with a highmagnitude zonal band between $17^{\circ} \mathrm{N}$ to $28^{\circ} \mathrm{N}$ (Fig. 2b). Regions with high FSLE are 20 known to be prone to submesoscale frontogenesis with increasing strain and deformation. The spatial correlation coefficient between mean FSLE and mean EKE is 0.76, suggesting that strong eddies are generally associated with intense submesoscale processes that are often concurrent with vertical motions.

One of the mostly used ocean color satellite-derived variables to probe biological activity is surface chlorophyll concentration (Chl). We computed the annual mean $\mathrm{Chl}$ during 1998-2007, the same period as in EKE calculation (Fig. 2c). Except for the slightly enhanced magnitude in the immediate lee corresponding to the highest EKE region $\left(>300 \mathrm{~cm}^{2} \mathrm{~s}^{-2}\right)$, Chl shows a completely different spatial pattern to EKE field

Physical-biological interactions to the west of Hawaiian Islands

P. Xiu and F. Chai

Title Page

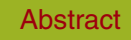

Introduction

Conclusions

Tables

References

Figures

14

4

Back

Full Screen / Esc

Printer-friendly Version

Interactive Discussion $\rightarrow 1$

Close 
with prominent concentration gradients in both zonal and meridional direction. High Chl signal in the immediate lee is very likely attributable to the eddy pumping in cyclonic eddy core and the submesoscale upwelling in anticyclonic eddy edge that brings high nutrient to the upper layer and supports high biological productivity (Bidigare et al., 5 2003; Kuwahara et al., 2008; Nencioli et al., 2008; Calil and Richards, 2010). To the west of this region, EKE magnitude reduces and nutricline depth deepens (not shown here). The combination of these two factors may result in the mismatch of spatial pattern between EKE and Chl.

Carbon and chlorophyll are two commonly used variables to quantify phytoplankton 10 biomass. However, due to the complex effect of light, temperature, and nutrient, these two variables are usually decoupled from each other (e.g., Behrenfeld et al., 2005; Xiu and Chai, 2012). Phytoplankton carbon production is typically regulated by photosynthetic rate, while phytoplankton chlorophyll production is controlled by both nutrient assimilation and light regulation, known as photoacclimation. The ratio, phytoplankton carbon-to-chlorophyll $(\mathrm{C}: \mathrm{Chl})$ generally decreasing from high light to low light has been used as an indicator to assess phytoplankton physiology from space and time (e.g., Behrenfeld et al., 2005; Wang et al., 2009; Li et al., 2010). VGPM PP estimated from surface chlorophyll concentration indicates a similar annual mean pattern in space to Chl (Fig. 3a) with the lowest in the southwest of the domain and a strong meridional gradient that are consistent with the spatial pattern of nutrients (nitrate and silicate) from WOA09.

CbPM PP calculated from phytoplankton carbon, however, differs a lot (Fig. 3b). A high CbPM PP band is found between $17^{\circ} \mathrm{N}$ and $28^{\circ} \mathrm{N}$ with small zonal gradient to the west of Hawaiian Islands that resembles the high EKE band (Fig. 2a). Moreover, this band is found to be occupied by shallower MLD than surrounding waters (Fig. 3c), which provides a dynamic link between CbPM PP and EKE. Sea surface winds are usually responsible for the MLD and its variability in most of the oceans and there is a low zonal band existing to the west of Hawaiian Islands. Two regional boxes are therefore used to examine the temporal correlations between monthly EKE, MLD, and
BGD

$10,12529-12549,2013$

Physical-biological interactions to the west of Hawaiian

Islands

P. Xiu and F. Chai

Title Page

Abstract Introduction

Conclusions

Tables

References

Figures

14

4

Back $\rightarrow 1$

Full Screen / Esc

Printer-friendly Version

Interactive Discussion 
wind speed (Fig. 3d). The northern box, located within a similar latitudinal rang as Hawaiian Islands depicts a high negative correlation between EKE and MLD $(r=-0.6)$ and a low positive correlation between wind speed and MLD $(r=0.2)$. In contrast, the southern box indicates a low positive correlation between EKE and MLD $(r=0.1)$ 5 and a high positive correlation between wind speed and MLD $(r=0.5)$. This suggests that eddy and frontal activities are primary factors in controlling MLD and upper ocean restratification in the high EKE band (e.g., the northern box region).

A snapshot of 8 day averaged CbPM PP around 11 February 2006 shows a similar spatial pattern with FSLE, where regions of enhanced CbPM are associated with high 10 FSLE values (Fig. 4a), whereas this spatial relationship is not clear between VGPM PP and FSLE (Fig. 4b). Comparisons between FSLE and MLD and between FSLE and EKE support that submesoscale frontal processes with high FSLE values arising from eddy activities are able to decrease mixed layer depth and restratify the upper ocean. In addition to the instantaneous case, climatological FSLE also indicates a high positive 15 spatial correlation with CbPM PP and with EKE, and a negative correlation with MLD, however, the correlation between FSLE and VGPM PP is relatively low (Fig. 5).

To further investigate interannual variations, we first divide the domain into high EKE region (EKE $>200 \mathrm{~cm}^{2} \mathrm{~s}^{-2}$ ) and low EKE region $\left(E K E<200 \mathrm{~cm}^{2} \mathrm{~s}^{-2}\right.$ ) during each month. We then calculate the averaged variable differences between these two regions (high EKE region-low EKE region) for each monthly data and further average them over the year to construct the annual mean terms (Fig. 6a). There are consistent positive values of CbPM PP and negative values of MLD during each year suggesting high EKE corresponding to high CbPM PP and low MLD. However, the relationship between EKE and VGPM PP is not clear on the annual mean basis, which is likely due to the influence of two competing processes induced by eddies, restratification that suppresses vertical mixing of deep nutrients and upwelling that brings nutrients up to the surface layer. This competing mechanism for chlorophyll-based PP is particularly effective in oligotrophic waters where nutricline depth is deep and the resultant upwelling nutrient flux is dampened.
BGD

$10,12529-12549,2013$

Physical-biological interactions to the west of Hawailian

Islands

P. Xiu and F. Chai

Title Page

Abstract Introduction

Conclusions

Tables

References

Figures

14

4

Back

Full Screen / Esc

Printer-friendly Version

Interactive Discussion 
Interannual EKE signal in this region has been suggested highly correlate with the Pacific Decadal Oscillation (PDO) index via modulating vertical shear of horizontal velocity (Yoshida et al., 2011). In addition, a significant negative correlation between EKE and the North Pacific Gyre Oscillation (NPGO) index is also found during 1998-2007 5 (Fig. 6b). As a consequence, eddy induced enhancement in CbPM PP indicates a significant positive correlation with PDO index $(r=0.82)$ and a robust negative correlation with NPGO index $(r=-0.77)$ as well, suggesting more carbon are fixed during positive PDO (negative NPGO) phase and less during negative PDO (positive NPGO) phase.

To summarize findings in this study, a conceptual model of the phytoplankton re-

sponses to eddy and frontal dynamics to the west of Hawaiian Islands is proposed (Fig. 7). Due to eddy-eddy or eddy-front interactions, high eddy activity creates regions with enhanced shear and straining that leads to rapid upper ocean restratification and submesoscale upward motions. The restratification process deceases MLD that would increase the mean exposure of the phytoplankton cells to light. As carbon-based PP produced from carbon-fixing photosynthesis is largely controlled by light levels in the water column, decreased MLD further results in enhanced carbon-based production. In the surface layer, increased light can decrease phytoplankton chlorophyll due to the photoacclimation effect, while it can also increase phytoplankton chlorophyll when light is a limiting factor for phytoplankton growth. In addition to light levels, chlorophyll-based $\mathrm{PP}$ is also controlled by availability of nutrient that is determined by two competing processes, ocean restratification and submesoscale upward motions. The connection between eddy and frontal activities and chlorophyll-based PP is therefore difficult to detect solely from satellite observations.

\section{Discussion}

25 Eddies are a ubiquitous feature over the global ocean. Their impacts on physical and biogeochemical properties through different processes have been widely observed and discussed (e.g., Bidigare et al., 2003; Kuwahara et al., 2008; Nencioli et al., 2008; Calil
BGD

$10,12529-12549,2013$

Physical-biological interactions to the west of Hawaiian

Islands

P. Xiu and F. Chai

Title Page

Abstract Introduction

Conclusions

Tables References Figures

14

4

Back

Full Screen / Esc

Printer-friendly Version

Interactive Discussion 
and Richards, 2010; Xiu and Chai, 2011). In this work, we present a new view how eddies affect biological productivity in oligotrophic waters via changing phytoplankton physiological conditions. While most of the studies focus on satellite-derived chlorophyll concentration that is thought to be a poor proxy for phytoplankton biomass (Behrenfeld 5 et al., 2005; Wang et al., 2009; Li et al., 2010; Xiu and Chai, 2012), this effect is generally neglected.

Results presented in this study is different from those conducted in high latitudes where nutrient is replete during winter and spring and light is a limiting factor for both phytoplankton photosynthetic carbon fixation and nutrient assimilation. Increasing 10 light due to eddy restratification can thus trigger phytoplankton carbon and chlorophyll blooms together (Lévy et al., 1999; Taylor and Ferrari, 2011; Mahadevan et al., 2012).

Summertime phytoplankton increases in the North Pacific gyre have been observed to be supported by $\mathrm{N}_{2}$-fixing organisms (e.g., Dore et al., 2008; Calil et al., 2011). Eddy induced upper ocean restratification constrains more diazotrophs in the upper layer, increases their chances to fix more $\mathrm{N}_{2}$ from atmosphere as an alternative nutrient source. In this scenario, variability of phytoplankton $\mathrm{C}: \mathrm{Chl}$ is mostly linked to photoacclimation with a relatively stable stoichiometry. Other than that, both vertical nutrient supply and light condition are responsible for observed variability in phytoplankton $C: C h$ ratio. When nutrient is depleted in the surface layer, photosynthetic carbon fixation can still continue leading to a deviated phytoplankton carbon to nitrogen ratio $(C: N)$ from the standard Redfield ratio.

While previous studies identified the role of eddy in triggering episodic vertical nutrient injection and stimulating phytoplankton blooms (Johnson et al., 2010; Calil et al., 2011), the long-term impact of eddies on phytoplankton productivity still needs to be investigated, especially to the west of Hawaiian Islands. Our study suggests that interannual variability of eddy induced phytoplankton carbon enhancement has a robust relationship with PDO (NPGO) index as a result of modulated eddy and frontal activities. This provides a potential dynamic link between climate variability and carbon cycle for this region.
BGD

10, 12529-12549, 2013

Physical-biological interactions to the west of Hawaiian

Islands

P. Xiu and F. Chai

Title Page

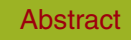

Introduction

Conclusions

Tables

References

Figures

14

4

Back

Full Screen / Esc

Printer-friendly Version

Interactive Discussion 
Acknowledgements. This research was supported by NASA grants (NNG04GM64G and NNX09AU39G) to F. Chai. The authors wish to thank SeaWiFS Project for providing the SeaWiFS data (http://oceancolor.gsfc.nasa.gov/). The altimeter products were produced by Ssalto/Duacs and distributed by Aviso, with support from Cnes (http://www.aviso.oceanobs. $5 \mathrm{com} /$ duacs/). Primary production and mixed layer depth data were obtained from http://www. science.oregonstate.edu/ocean.productivity/. We thank all the scientists and ship's crew who collected and analyzed data for the Hawaii Ocean Time-series. We thank Peter Strutton for his insightful advice on this manuscript.

\section{References}

Behrenfeld, M. J. and Falkowski, P. G.: Photosynthetic rates derived from satellite-based chlorophyll concentration, Limnol. Oceanogr., 42, 1-20, 1997.

Behrenfeld, M. J., Boss, E., Siegel, D. A., and Shea, D. M.: Carbon-based ocean productivity and phytoplankton physiology from space, Global Biogeochem. Cy., 19, GB1006, doi:10.1029/2004GB002299, 2005.

Bidigare, R. R., Benitez-Nelson, C., Leonard, C. L., Quay, P. D., Parsons, M. L., Foley, D. G., and Seki, M. P.: Influence of a cyclonic eddy on microheterotroph biomass and carbon export in the lee of Hawaii, Geophys. Res. Lett., 30, 1318, doi:10.1029/2002GL016393, 2003.

Boccaletti, G., Ferrari, R., and Fox-Kemper, B.: Mixed layer instabilities and restratification, J. Phys. Oceanogr., 37, 2228-2250, 2007.

Calil, P. H. R., Richards, K. J., Jia, Y., and Bidigare, R. R.: Eddy activity in the lee of the Hawaiian Islands, Deep-Sea Res. Pt. II, 55, 10-13, doi:10.1016/j.dsr2.2008.01.008, 2008.

Calil, P. H. R. and Richards, K. J.: Transient upwelling hot spots in the oligotrophic North Pacific, J. Geophys. Res., 115, C02003, doi:10.1029/2009JC005360, 2010.

Calil, P. H. R., Doney, S. C., Yumimoto, K., Eguchi, K., and Takemura, T.: Episodic upwelling and dust deposition as bloom triggers in low-nutrient, low-chlorophyll regions, J. Geophys. Res., 116, C06030, doi:10.1029/2010JC006704, 2011.

d'Ovidio, F., Fernandez, V., Hernandez-Garca, E., and Lopez, C.: Mixing structures in the Mediterranean Sea from finite-size Lyapunoov exponent, Geophys. Res. Lett., 31, L17203, doi:10.1029/2004GL020328, 2004.
BGD

$10,12529-12549,2013$

Physical-biological

interactions to the

west of Hawailian

Islands

P. Xiu and F. Chai

Title Page

Abstract

Introduction

Conclusions

Tables

References

Figures

14

4

Back

Close

Full Screen / Esc

Printer-friendly Version

Interactive Discussion 
d'Ovidio, F., Isern-Fontanet, J., Lopez, C., Hernandez-Garcia, E., and Garcia-Ladona, E.: Comparison between Eulerian diagnostics and finite-size Lyapunov exponents computed from altimetry in the Algerian basin, Deep-Sea Res. Pt. I, 56, 15-31, 2009.

Dore, J., Letelier, R., Church, M., Lukas, R., and Karl, D.: Summer phytoplankton blooms in the oligotrophic North Pacific Subtropical Gyre: historical perspective and recent observations, Prog. Oceanogr., 76, 2-38, 2008.

Fox-Kemper, B., Ferrari, R., and Hallberg, R.: Parameterization of mixed layer eddies. Part I: Theory and diagnosis, J. Phys. Oceanogr., 38, 1145-1165, 2008.

Garcia, H. E., Locarnini, R. A., Boyer, T. P., Antonov, J. I., Zweng, M. M., Baranova, O. K., and Johnson, D. R.: World Ocean Atlas 2009, vol. 4, Nutrients (phosphate, nitrate, silicate), edited by: Levitus, S., NOAA Atlas NESDIS 71, US Government Printing Office, Washington, D. C., 398 pp., 2010.

Jia, Y., Calil, P. H. R., Chassignet, E. P., Metzger, E. J., Potemra, J. T., Richards, K. J., and Wallcraft, A. J.: Generation of mesoscale eddies in the lee of the Hawaiian Islands, J. Geophys. Res., 116, C11009, doi:10.1029/2011JC007305, 2011.

Johnson, K., Riser, S., and Karl, D.: Nitrate supply from deep to near-surface waters of the North Pacific subtropical gyre, Nature, 465, 1062-1065, doi:10.1038/nature09170, 2010.

Klein, P. and Lapeyre, G.: The oceanic vertical pump induced by mesoscale and submesoscale turbulence, Annu. Rev. Mar. Sci., 1, 351-375, 2009.

Kobashi, F. and Kawamura, H.: Seasonal variation and instability nature of the North Pacific subtropical countercurrent and the Hawaiian Lee Countercurrent, J. Geophys. Res., 107, 3185, doi:10.1029/2001JC001225, 2002.

Kuwahara, V. S., Nencioli, F., Dickey, T. D., Rii, Y. M., and Bidigare, R. R.: Physical dynamics and biological implications of Cyclone Noah in the lee of Hawaii during E-Flux I, Deep-Sea Res. Pt. II, 55, 1231-1251, 2008.

Lapeyre, G., Klein, P., and Hua, B. L.: Oceanic restratification forced by surface frontogenesis, J. Phys. Oceanogr., 36, 1577-1590, 2006.

Lehahn, Y., d'Ovidio, F., Lévy, M., and Heifetz, E.: Stirring of the northeast Atlantic spring bloom: a Lagrangian analysis based on multisatellite data, J. Geophys. Res., 112, C08005, doi:10.1029/2006JC003927, 2007.

Lévy, M., Mémery, L., and Madec, G.: The onset of the spring bloom in the MEDOC area: mesoscale spatial variability, Deep-Sea Res. Pt. I, 46, 1137-1160, 1999.
BGD

10, 12529-12549, 2013

Physical-biological

interactions to the

west of Hawailian

Islands

P. Xiu and F. Chai

Title Page

Abstract

Introduction

Conclusions

Tables

References

Figures

14

4

Back

Full Screen / Esc

Printer-friendly Version

Interactive Discussion 
Lévy, M., Klein, P., and Treguier, A.-M.: Impact of sub-mesoscale physics on production and subduction of phytoplankton in an oligotrophic regime, J. Mar. Res., 59, 535-565, 2001.

Li, Q. P., Franks, P. J. S., Landry, M. R., Goericke, R., and Taylor, A. G.: Modeling phytoplankton growth rates and chlorophyll to carbon ratios in California coastal and pelagic ecosystems,

$5 \quad J$. Geophys. Res., 115, G04003, doi:10.1029/2009JG001111, 2010.

Liu, Q., Wang, S., Wang, Q., and Wang, W.: On the formation of subtropical countercurrent to the west of the Hawaiian Islands, J. Geophys. Res., 108, C53167, doi:10.1029/2002JC001366, 2003.

Mahadevan, A. and Tandon, A.: An analysis of mechanisms for submesoscale vertical motion at ocean fronts, Ocean Model., 14, 241-256, 2006.

Mahadevan, A., Tandon, A., and Ferrari, R.: Rapid changes in mixed layer stratification driven by submesoscale instabilities and winds, J. Geophys. Res., 115, C03017, doi:10.1029/2008JC005203, 2010.

Mahadevan, A., D'Asaro, E., Perry, M.-J., and Lee, C.: Eddy-driven stratification initiates North

15 Atlantic Spring phytoplankton blooms, Science, 337, 54-58, doi:10.1126/science.1218740, 2012.

Nencioli, F., Kuwahara, V. S., Dickey, T. D., Rii, Y. M., and Bidigare, R. R.: Physical dynamics and biological implications of a mesoscale eddy in the lee of Hawaii: cyclone Opal observations during E-Flux III, Deep-Sea Res. Pt. II, 55, 1252-1274, 2008.

Qiu, B. and Chen, S.: Interannual variability of the North Pacific subtropical countercurrent and its associated mesoscale eddy field, J. Phys. Oceanogr., 40, 213-225, doi:10.1175/2009JPO4285.1, 2010.

Sasaki, H., Xie, S. P., Taguchi, B., Nonaka, M., and Masumoto, Y.: Seasonal variations of the Hawaiian Lee Countercurrent induced by the meridional migration of the Trade Winds, Ocean Dyn., 60, 705-715, doi:10.1007/s10236-009-0258-6, 2010.

Taylor, J. R. and Ferrari, R.: Ocean fronts trigger high latitude phytoplankton blooms, Geophys. Res. Lett., 38, L23601, doi:10.1029/2011GL049312, 2011.

Wang, X., Le Borgne, R., Murtugudde, R., Busalacchi, A. J., and Behrenfeld, M.: Spatial and temporal variability of the phytoplankton carbon to chlorophyll ratio in the equatorial Pacific: so a basin-scale modeling study, J. Geophys. Res., 114, C07008, doi:10.1029/2008JC004942, 2009.

P. Xiu and F. Chai

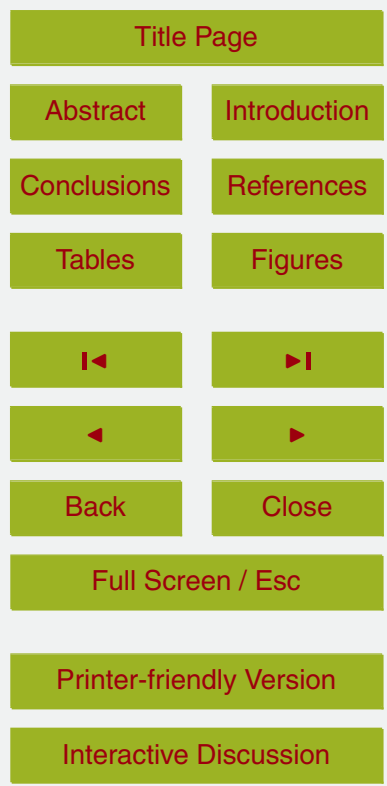


Westberry, T., Behrenfeld, M. J., Siegel, D. A., and Boss, E.: Carbon-based primary productivity modeling with vertically resolved photoacclimation, Global Biogeochem. Cy., 22, GB2024, doi:10.1029/2007GB003078, 2008.

Xie, S. P., Liu, W. T., and Nonaka, M.: Far-reaching effects of the Hawaiian Islands on the Pacific 5 ocean-atmosphere system, Science, 292, 2057-2069, doi:10.1126/science.1059781, 2001.

Xiu, P. and Chai, F.: Modeled biogeochemical responses to mesoscale eddies in the South China Sea, J. Geophys. Res., 116, C10006, doi:10.1029/2010JC006800, 2011.

$\mathrm{Xiu}, \mathrm{P}$. and Chai, F.: Spatial and temporal variability in phytoplankton carbon, chlorophyll, and nitrogen in the North Pacific, J. Geophys. Res., 117, C11023, doi:10.1029/2012JC008067, 2012.

Xiu, P., Chai, F., Xue, H., Shi, L., and Chao, Y.: Modeling the mesoscale eddy field in the Gulf of Alaska, Deep-Sea Res. Pt. I, 63, 102-117, 2012.

Yoshida, S., Qiu, B., and Hacker, P.: Wind-generated eddy characteristics in the lee of the island of Hawaii, J. Geophys. Res., 115, C03019, doi:10.1029/2009JC005417, 2010.

Yoshida, S., Qiu, B., and Hacker, P.: Low-frequency eddy modulations in the Hawaiian Lee Countercurrent: observations and connection to the Pacific Decadal Oscillation, J. Geophys. Res., 116, C12009, doi:10.1029/2011JC007286, 2011.

Physical-biological

interactions to the

west of Hawaiian

Islands

P. Xiu and F. Chai

Title Page

Abstract Introduction

Conclusions References

Tables Figures

14

$>$ I

4

Back

Close

Full Screen / Esc

Printer-friendly Version

Interactive Discussion 


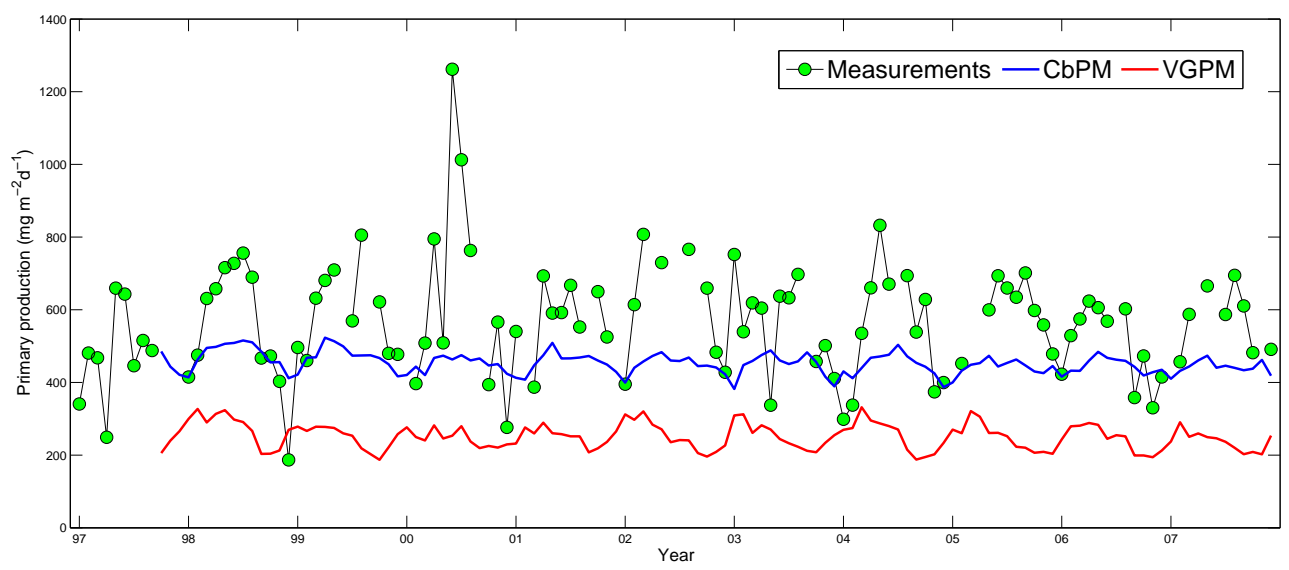

Fig. 1. Comparison of CbPM and VGPM derived primary production with in-situ observations at a fixed station ALOHA (a long-term oligotrophic habitat assessment; $22^{\circ} 45^{\prime} \mathrm{N}, 158^{\circ} \mathrm{W}$ ).

\section{BGD}

10, 12529-12549, 2013

Physical-biological interactions to the west of Hawailian

Islands

P. Xiu and F. Chai

\section{Title Page}

\section{Abstract}

Introduction

Conclusions

References

Tables

Figures

14

$\rightarrow 1$

4

Back

Close

Full Screen / Esc

Printer-friendly Version

Interactive Discussion 
a. $\operatorname{EKE}\left(\mathrm{cm}^{2} \mathrm{~s}^{-2}\right)$

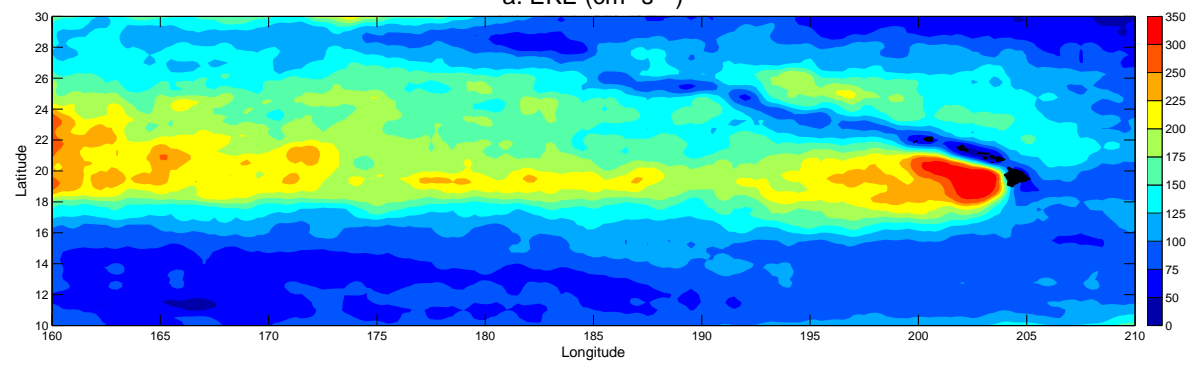

b. FSLE $\left(d^{-1}\right)$

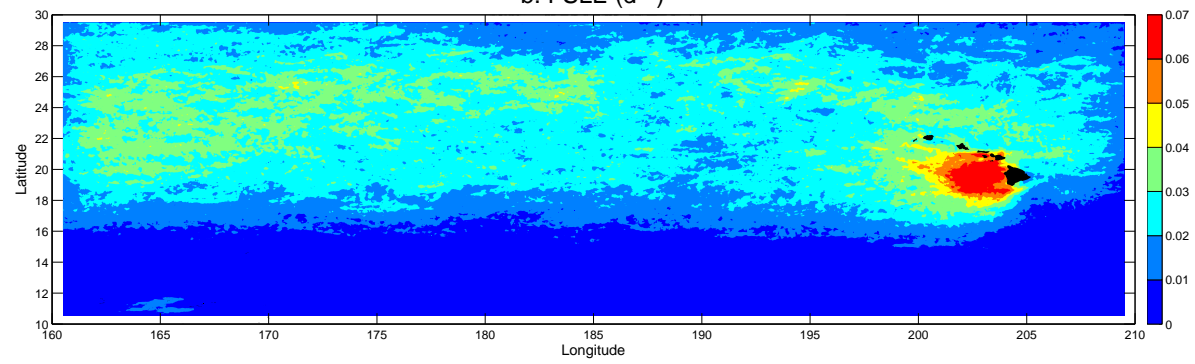

c. Chlorophyll $\left(\mathrm{mg} \mathrm{m}^{-3}\right)$

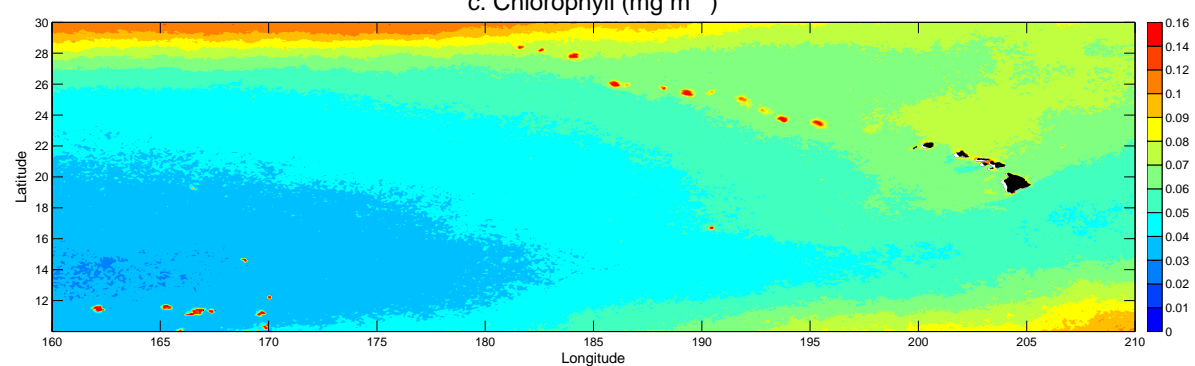

Fig. 2. Climatological mean of eddy kinetic energy (EKE), FSLE and SeaWiFS derived surface chlorophyll concentration averaged over 1998-2007.

\section{BGD}

$10,12529-12549,2013$

Physical-biological interactions to the west of Hawaiian Islands

P. Xiu and F. Chai

Title Page

Abstract

Introduction

Conclusions

References

Tables

Figures

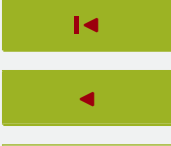

I

Back

Close

Full Screen / Esc

Printer-friendly Version

Interactive Discussion

(c) (i) 

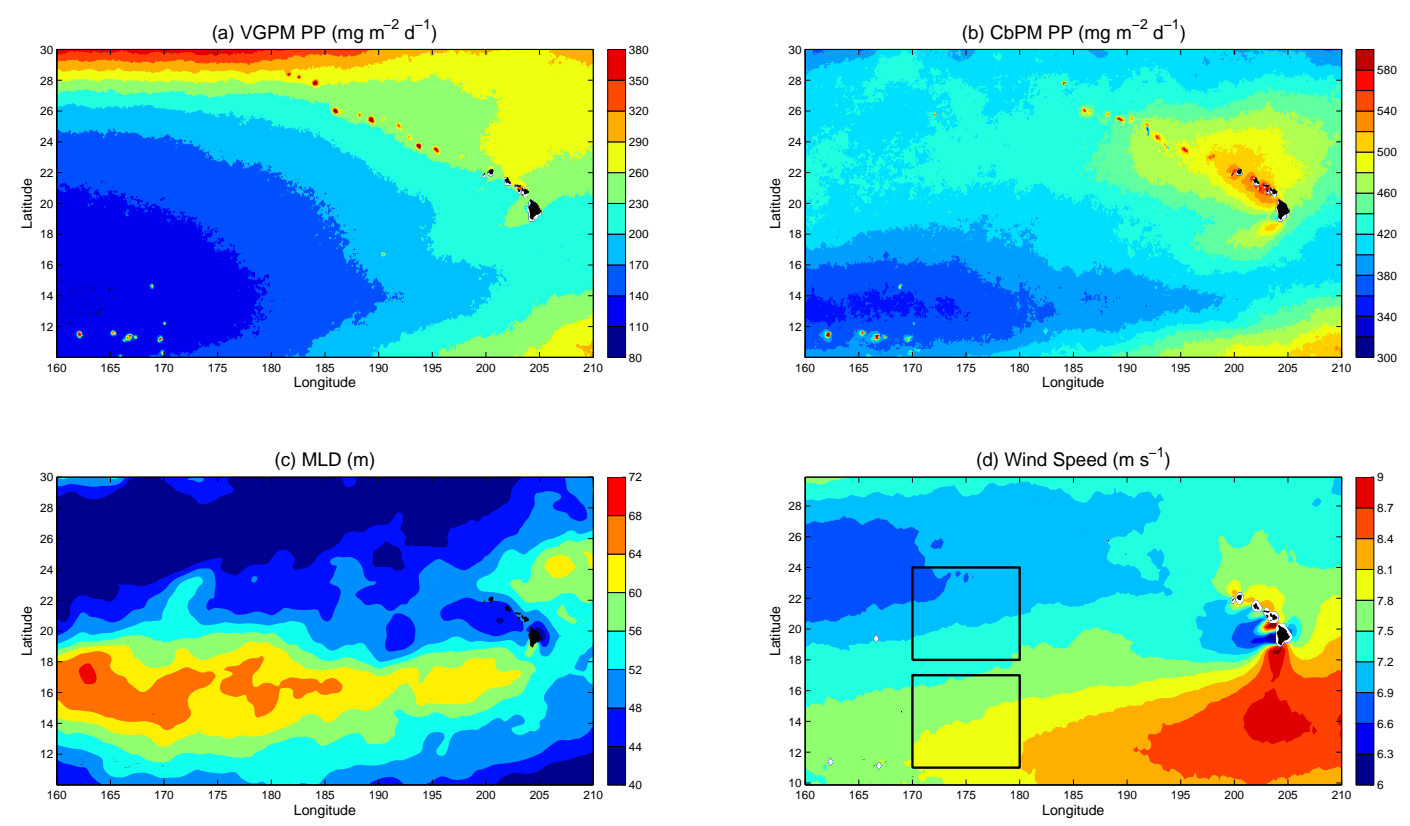

Fig. 3. Climatological mean of (a) VGPM derived primary production, (b) CbPM derived primary production, (c) mixed layer depth, and (d) wind speed averaged over 1998-2007.

\section{BGD}

$10,12529-12549,2013$

Physical-biological interactions to the west of Hawaiian

\section{Islands}

P. Xiu and F. Chai

\section{Title Page}

\section{Abstract}

Introduction

Conclusions

References

Tables

Figures

14

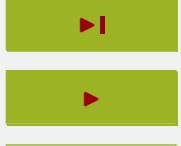

Back

Close

\section{Full Screen / Esc}

Printer-friendly Version

Interactive Discussion 

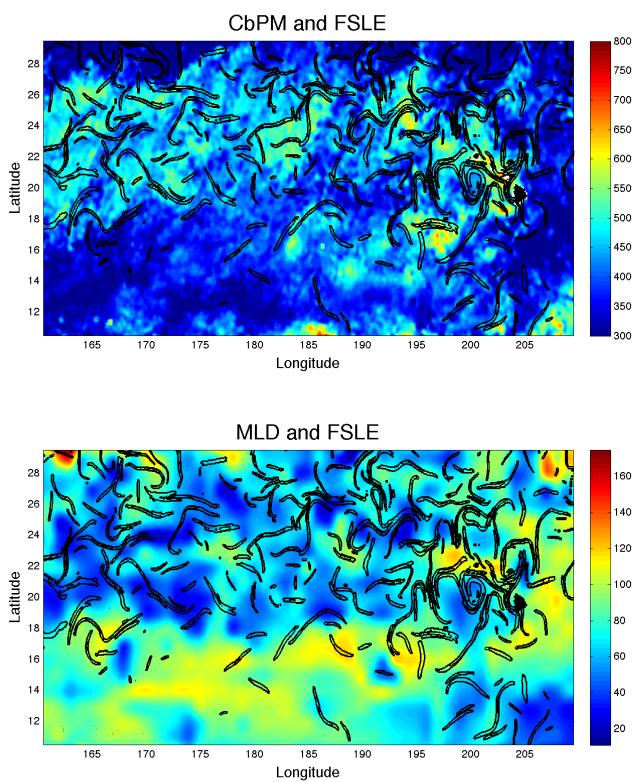
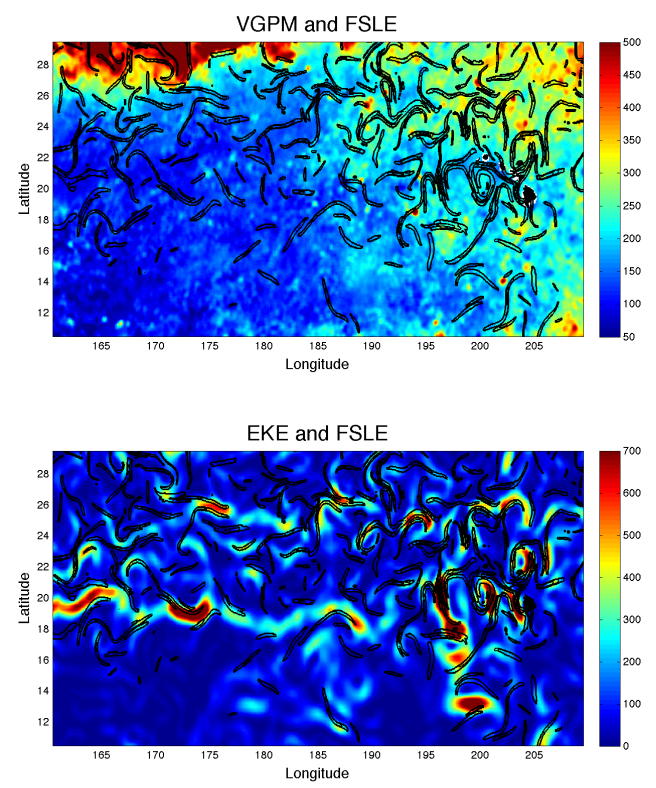

Fig. 4. A snapshot of CbPM PP $\left(\mathrm{mg} \mathrm{m}^{-2} \mathrm{~d}^{-1}\right)$, VGPM PP $\left(\mathrm{mg} \mathrm{m}^{-2} \mathrm{~d}^{-1}\right), \operatorname{MLD}(\mathrm{m})$, and EKE $\left(\mathrm{cm}^{2} \mathrm{~s}^{-2}\right)$ in colors. Overlaid black contours mark high FSLE $\left(\mathrm{d}^{-1}\right)$ regions.

Physical-biological interactions to the west of Hawailian Islands

P. Xiu and F. Chai

Title Page

Abstract

Introduction

Conclusions

References

Tables

Figures

14

4

$\rightarrow 1$

$\rightarrow$

Back

Close

Full Screen / Esc

Printer-friendly Version

Interactive Discussion 

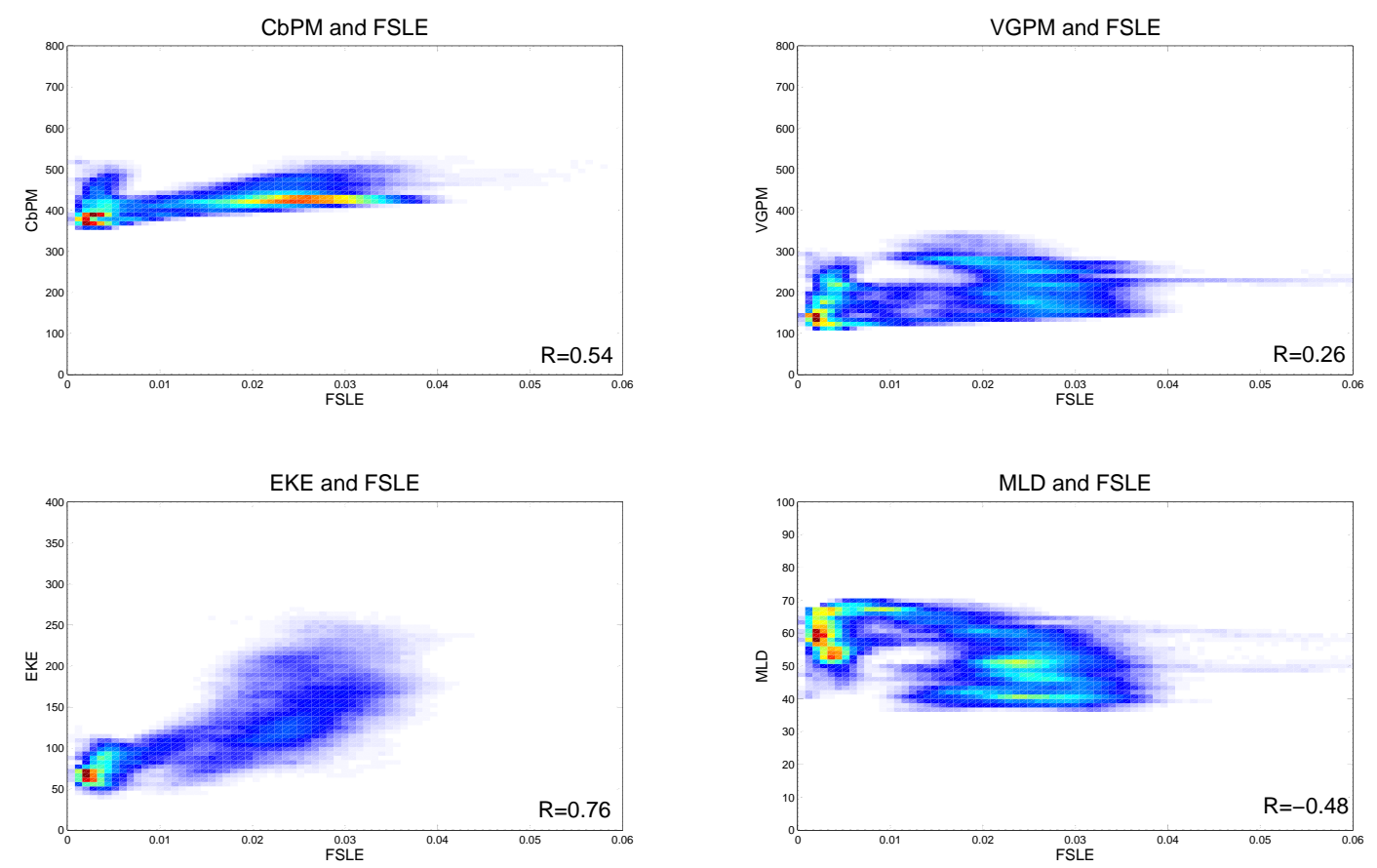

Fig. 5. Density plots of spatial distributions between mean CbPM PP $\left(\mathrm{mg} \mathrm{m}^{-2} \mathrm{~d}^{-1}\right)$ and FSLE $\left(\mathrm{d}^{-1}\right)$, VGPM PP $\left(\mathrm{mg} \mathrm{m}^{-2} \mathrm{~d}^{-1}\right)$ and FSLE, EKE $\left(\mathrm{cm}^{2} \mathrm{~s}^{-2}\right)$ and FSLE, MLD $(\mathrm{m})$ and FSLE. Warm color represents high data density, and cold color represents low data density.

BGD

$10,12529-12549,2013$

Physical-biological interactions to the west of Hawailian

Islands

P. Xiu and F. Chai

\section{Title Page}

\section{Abstract}

Introduction

Conclusions

References

Tables

Figures

14

$\rightarrow$ I

4

Back

Close

Full Screen / Esc

Printer-friendly Version

Interactive Discussion 
(a)

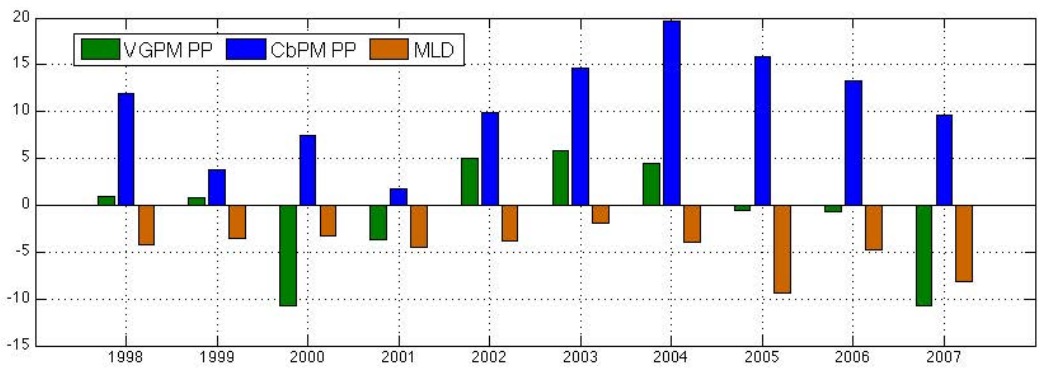

(b)

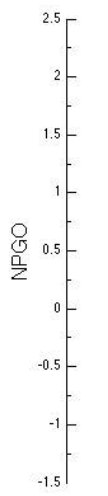

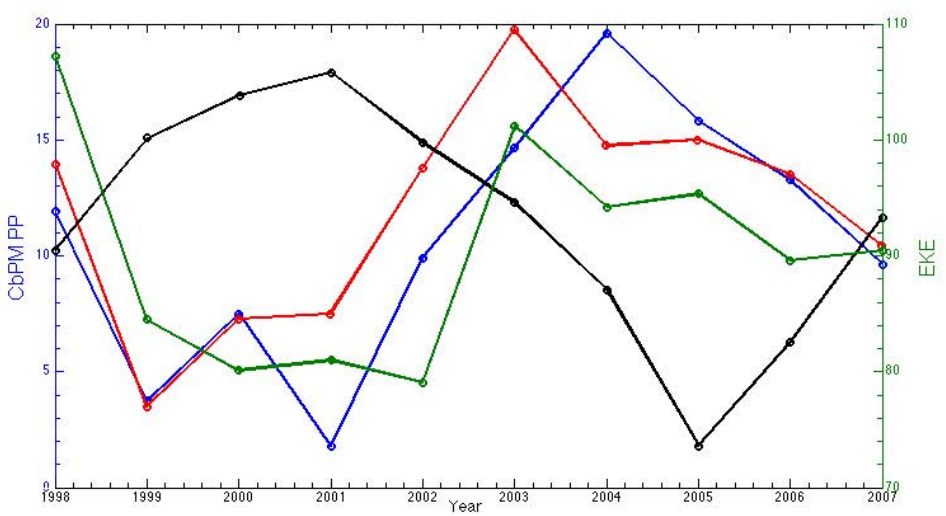

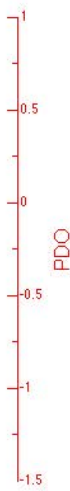

Fig. 6. (a) Primary production (VGPM and CbPM; unit: $\mathrm{mgm}^{-2} \mathrm{~d}^{-1}$ ) and mixed layer depth (unit: $\mathrm{m}$ ) differences between high EKE region $\left(E K E>200 \mathrm{~cm}^{2} \mathrm{~s}^{-2}\right.$ ) and low EKE region (EKE < $200 \mathrm{~cm}^{2} \mathrm{~s}^{-2}$ ) (high EKE region-low EKE region) for each monthly data (further averaged over the year). (b) Comparison of CbPM PP difference (unit: $\mathrm{mg} \mathrm{m}^{-2} \mathrm{~d}^{-1}$ ) with domain-averaged EKE, Pacific Decadal Oscillation (PDO) index and North Pacific Gyre Oscillation (NPGO) index during 1998-2007.
BGD

$10,12529-12549,2013$

Physical-biological interactions to the west of Hawailan

Islands

P. Xiu and F. Chai

Title Page

Abstract Introduction

Conclusions

References

Tables

Figures

14

>

4

Back

Close

Full Screen / Esc

Printer-friendly Version

Interactive Discussion 


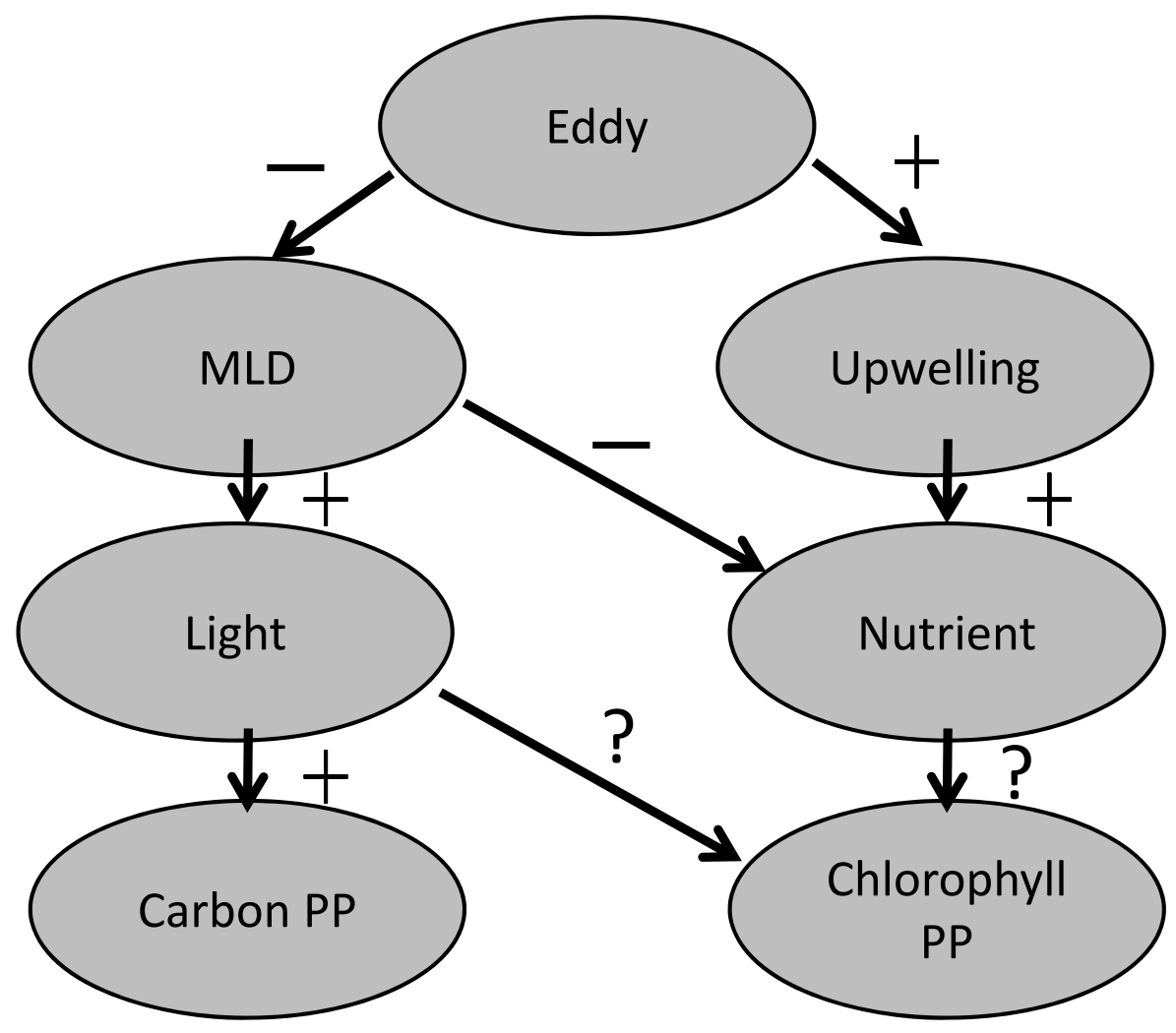

$10,12529-12549,2013$

Physical-biological interactions to the west of Hawaiian

Islands

P. Xiu and F. Chai

Title Page

Abstract

Introduction

Conclusions

References

Tables

Figures

14

$>$ I

4

Back

Close

Full Screen / Esc

Fig. 7. A conceptual model depicting how eddy affect phytoplankton production to the west of Hawaiian Islands. The "+" represents a positive response, the "-" represents a negative response, and the "?" represents both possible directional responses.

Printer-friendly Version

Interactive Discussion 